\title{
Insufficient protection by Neisseria meningitidis vaccination alone during eculizumab therapy
}

\author{
Antonia Bouts • Leo Monnens • Jean-Claude Davin • \\ Geertrude Struijk • Lodewijk Spanjaard
}

Received: 13 April 2011 /Revised: 18 April 2011 /Accepted: 18 April 2011 /Published online: 5 June 2011

(C) The Author(s) 2011. This article is published with open access at Springerlink.com

Sirs,

Spurred by the reported spectacular results of eculizumab treatment in atypical hemolytic uremic syndrome (aHUS) due to aberrations in the complement system, an increasing number of children will receive this treatment in future. The main adverse effect of this therapy is an increased susceptibility to meningococcal infection due to inhibition of the complement system's membrane-attack complex. In patients with paroxysmal nocturnal hemoglobinuria treated with eculizumab, the reported occurrence of meningococcal infection is between $0 \%$ and $1.5 \%[1-3]$. These data,

\footnotetext{
A. Bouts $(\bowtie) \cdot$ J.-C. Davin

Department of Pediatric Nephrology, Emma Children's Hospital, Academic Medical Center,

Meibergdreef 9,

Amsterdam 1105 AZ, The Netherlands

e-mail: a.h.bouts@amc.uva.nl

L. Monnens

Department of Physiology, University Medical Center Nijmegen, Nijmegen, The Netherlands

G. Struijk

Department of Nephrology, Division of Internal Medicine,

Academic Medical Center,

Amsterdam, The Netherlands

L. Spanjaard

Netherlands Reference Laboratory for Bacterial Meningitis, Department of Medical Microbiology, Academic Medical Center, Amsterdam, The Netherlands
}

concerning adult patients, cannot be extrapolated to children because the age-specific incidence of meningococcal disease is much higher in children.

According to the medication guide of the U.S. Food and Drug Administration, a tetravalent unconjugated polysaccharide vaccine (serogroups $\mathrm{A}, \mathrm{C}, \mathrm{Y}, \mathrm{W} 135$ ) has to be provided at least 2 weeks before the first dose of eculizumab. In our opinion, this approach is not sufficient for prevention in many countries, because none of the available vaccines contains a serogroup B antigen [4]. The serogroup distribution among meningococcal infections in The Netherlands is presented in Fig. 1. Since June 2002, a conjugated vaccine against serogroup $\mathrm{C}$ has been included in the national immunization program. In 2009, $84 \%$ of isolates belonged to serogroup B, $7 \%$ to serogroup $\mathrm{C}$, and the remaining to other serogroups, such as $\mathrm{X}, \mathrm{Y}$, and $\mathrm{W} 135$ [5]. Thus, the advised vaccination only offers limited protection. The peak incidence of serogroup B meningococcal disease is in children younger than 5 years and between the age of 15 to 19 years. Based on the risk of meningococcal infection in children treated with eculizumab and the high prevalence of serogroup B disease that cannot yet be prevented by vaccination, penicillin prophylaxis should not only be considered [6] but strongly advised to patients. Beside this, vaccination with a conjugated vaccine might give better protection than the unconjugated polysaccharide vaccine [7]. Serogroup B prevalence is highest not only in The Netherlands but in the rest of Europe and other parts of the world [8]. The best strategy depends on the distribution of meningococcal serogroups and the availability of vaccines in different countries [9]. 
Fig. 1 Distribution of meningococcal serogroups 1959-2009 (adapted from Netherlands Reference Laboratory for Bacterial Meningitis, used with permission)

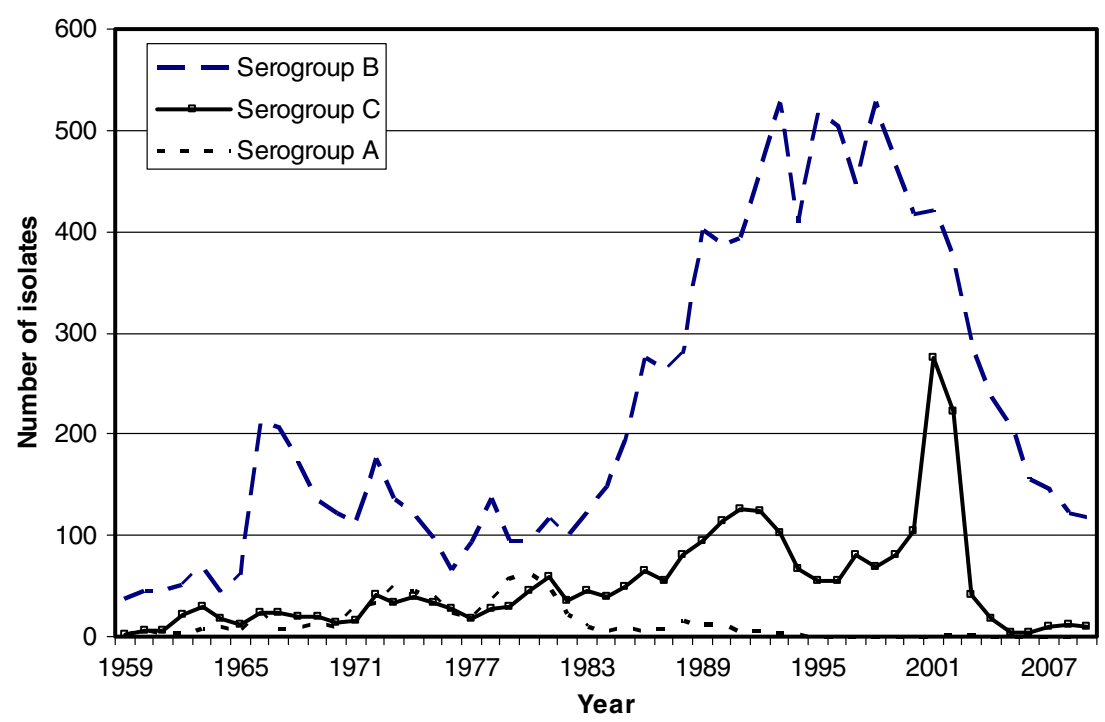

Open Access This article is distributed under the terms of the Creative Commons Attribution Noncommercial License which permits any noncommercial use, distribution, and reproduction in any medium, provided the original author(s) and source are credited.

\section{References}

1. Brodsky RA, Young NS, Antonioli E, Risitano AM, Schrezenmeier H, Schubert J, Gaya A, Coyle L, de Castro C, Maciejewski JP, Bessler M, Kroon HA, Rother RP, Hillmen P (2008) Multicenter phase 3 study of the complement inhibitor eculizumab for the treatment of patients with paroxysmal nocturnal hemoglobinuria. Blood 111:1840-1847

2. Hillmen P, Elebute M, Kelly R, Urbano-Ispizua A, Hill A, Rother RP, Khursigara G, Fu CL, Omine M, Browne P, Rosse W (2010) Long-term effect of the complement inhibitor eculizumab on kidney function in patients with paroxysmal nocturnal hemoglobinuria. Am J Hematol 85:553-559
3. Dmytrijuk A, Robie-Suh K, Cohen MH, Rieves D, Weiss K, Pazdur R (2008) FDA report: eculizumab (Soliris ${ }^{\circledR}$ ) for the treatment of patients with paroxysmal nocturnal hemoglobinuria. Oncologist 13:993-1000

4. Gardner P (2006) Prevention of meningococcal disease. N Engl J Med 355:1466-1473

5. Netherlands Reference laboratory for bacterial meningitis (AMC/ RIVM). Bacterial Meningitis in the Netherlands; annual report 2009. Amsterdam: University of Amsterdam, 2010

6. Waters AM, Licht C (2011) aHUS caused by complement dysregulation: new therapies on the horizon. Pediatr Nephrol 26(1):41-57

7. Memish ZA, Dbaibo G, Montellano M, Verghese VP, Jain H, Dubey AP, Bianco V, Van der Wielen M, Gatchalian S, Miller JM (2011) Immunogenicity of a single dose of tetravalent meningococcal serogroups $\mathrm{A}, \mathrm{C}, \mathrm{W}-135$, and $\mathrm{Y}$ conjugate vaccine administered to 2to 10 -year-olds is noninferior to a licenced-ACWY polysaccharide vaccine with an acceptable safety profile. Ped Infect Dis J 30(4):e56-e62

8. Harrison LH, Trotter CL, Ramsay ME (2009) Global epidemiology of meningococcal disease. Vaccine 27S:B51-B63

9. Hart CA, Thomson APJ (2006) Meningococcal disease and its management in children. BMJ 333:685-6090 